\title{
Urban development and the importance of chamfers in corners lots: the case of Juína municipality, Mato Grosso State
}

\author{
Desenvolvimento urbanístico e a importância dos chanfros dos lotes de \\ esquinas: o caso do município de Juína, estado de Mato Grosso \\ Desarrollo urbanístico y la importancia de los chanfros de los lotes de \\ esquinas: el caso del municipio de Juina, estado de Mato Grosso
}

Le développement urbain et l'importance des faisceaux de coins: le cas de la municipalité de Juína, état du Mato Grosso

\author{
Rildo Vieira de Araújo ${ }^{1}$ \\ Halan Faria Lima ${ }^{1}$ \\ Leonice Barros Galvão ${ }^{1}$ \\ Reginaldo Brito da Costa ${ }^{1}$
}

Recebido em 13/04/2018; revisado e aprovado em 26/07/2018; aceito em 10/08/2018

DOI: http://dx.doi.org/10.20435/inter.v20i1.1932

\begin{abstract}
The study aimed at identifying and analyzing urban development in the city of Juína, MT, focusing on corner lots chamfers and their importance for the visibility of pedestrians and vehicles. It was found that corners and their respective chamfers did not present a pattern, whereas in others, there were no bevels. This reality occurs in many municipalities in Brazil.

Keywords: vehicle and pedestrian safety; city spaces; urban mobility.

Resumo: O estudo objetivou identificar e analisar o desenvolvimento urbanístico da cidade de Juína, MT, com foco nos chanfros dos lotes de esquinas e sua importância para a visibilidade de pedestres e veículos. Verificou-se que as esquinas com seus respectivos chanfros não possuem um padrão e inexistem em outras. Esta realidade ocorre em muitos municípios do Brasil.

Palavras-chave: segurança de veículos e pedestres; espaços das cidades; mobilidade urbana.

Resumen: El estudio objetivó identificar y analizar el desarrollo urbanístico de la ciudad de Juina, MT, con foco en los bisel de los lotes de esquinas y su importancia para la visibilidad de peatones y vehículos. Se verificó que las esquinas con sus respectivos chanfros no poseen un patrón y no existen en otras. Esta realidad ocurre en muchos municipios de Brasil.

Palabras clave: seguridad de vehículos y peatones; espacios de las ciudades; movilidad.

Résumé: L'étude visait à identifier et analyser le développement urbain de la ville de Juína, MT, en se concentrant sur les chanfreins des nombreux coins et leur importance pour la visibilité des piétons et des véhicules. Il a été constaté que les coins avec leurs chanfreins respectifs n'ont pas de motif et n'existent pas dans d'autres. Cette réalité se manifeste dans de nombreuses municipalités du Brésil.

Mots-clés: la sécurité des véhicules et des piétons; les espaces urbains; la mobilité urbaine.
\end{abstract}

\section{INTRODUCTION}

Expansion of cities in a disorderly way creates serious problems with regard to urban structure. In view of the territorial expansion of municipalities, there is a need to invest in improvements such as reorganization and replanning of urban space. UN-Habitat (2013) mentions that cities that contemplate integration between infrastructure and environmental sustainability have a high level of organization associated to traffic of vehicles and pedestrians, reducing

\footnotetext{
${ }^{1}$ Federal Institute of Mato Grosso (IFMT), Barra do Garças, Mato Grosso, Brasil.
} 
problems related to mobility and accessibility in the public space and projecting streets so that pedestrians and cyclists have adequate spaces.

Federal Law n. 6766/79 constitutes a pertinent legal instrument that defines and establishes guidelines for the division of urban lands throughout the country. This law came into force on December 19, 1979, revised and amended by the Federal Supplementary Law 9785/99, and became a legal framework of urban ground division up to the present day, treating the subject in a more systematic and coherent way (BRASIL, 1979).

Although the aforementioned law does not address issues diametrically related to urban planning of corner lots chamfers and crossings are a responsibility of the city council, there are several irregularities that hinder drivers and pedestrians. One is the lack of visibility that occurs by the absence of chamfer, a term understood as the corner lots edges required cut formed by the perpendicular to the bisector of the two frontages angle. For Mascaró (2003), the presented crossings options point out exteriorities related to pedestrians' safety and convenience in the use of roads; furthermore, it should be observed that roads crossings shaping is not only connected to their tracing, but also to aspects related to traffic organization and control, as well as bend radius of roads junctions and corner lots projections. The various externalities restrict visibility of pedestrians and vehicle drivers.

In this context, the present study aimed at identifying and analyzing urban development in the city of Juína, MT, focusing on corner lots chamfers and their importance to mobility, accessibility and visibility of pedestrians and vehicles.

\subsection{Some cases about chamfers in different municipalities from Brazil}

An understanding of urban context under the perspective of laws and decrees that regulate lots chamfers in the urban planning of Brazilian cities will lead to the fact that many city halls (Table 1) have ground division supplementary laws that direct and indirectly cite guidelines and regulations of the adequacy of corner lots chamfers present in neighborhoods and municipalities sectors.

Table 1 - Municipalities that directly or indirectly cite "chamfer" in their ground division laws

\begin{tabular}{|l|l|l|}
\hline CITY & GROUND DIVISION LAW & CHAMFER LOT \\
\hline Apucarana/PR & Law n. 179 of December 26, 2003 & Regulated \\
\hline Balneário Camboriú/Santa Catarina & Law n. 301 of December 13, 1974 & Regulated \\
\hline Campo Grande/MS & Suplementary Law 264/2015 & Regulated \\
\hline Cariacica/Espirito do Santo & Law n. 546/71 & Regulated \\
\hline Cuiabá/MT & Suplementary Law n. 102 of December 3, 2003 & Regulated \\
\hline Curitiba/PR & Law 11.095/2004 & Regulated \\
\hline Dourados/MS & Law n. 1391 of September 11, 1986 & Regulated \\
\hline Francisco Beltrão/PR & Law n. 3372 of July 13, 2007 & Regulated \\
\hline Goiânia/GO & Suplementary Law n. 177 of January 9, 2008 & Regulated \\
\hline Guarapuava/PR & Law n. 2074/2012 & Regulated \\
\hline Nova Xavantina/MT & Municipal Law n. 2028 of October 20, 2017 & Regulated \\
\hline Palmas/Tocantins & Law n. 45/90 & Regulated \\
\hline Rondonópolis/MT & Law n. 2120 of March 14, 1994 & Regulated \\
\hline Santo André/SP & Law n. 8836 of May 10, 2006 & Regulated \\
\hline São Paulo & Decree n. 46.932 of January 23, 2006 & Regulated \\
\hline
\end{tabular}




\section{CITY}

Sorriso/MT

Uberaba/MG

Source: Websites of City Halls. Compiled by the authors in 2018.

\section{GROUND DIVISION LAW}

Law n. 249 of July 07, 1992

Supplementary Law n. 375
CHAMFER LOT

Regulated

Regulated

City halls of Goiânia, GO, Francisco Beltrão, PR, and Rondonópolis, MT, are highlights among municipalities, for besides mentioning in their legislation the issue in focus, they also feature in their master plans procedures that meet particularities of chamfers. The Master Plan, or Director Plan (PD), shall direct public order norms that may regulate urban property use, being a decision-making tool for an integrated public management (CORRÊA et al, 2010). In summary, PD and ground division law are essential tools for municipalities' urban planning, which aim is to guarantee city development in a balanced and sustainable way.

A document of the city hall of Goiânia, GO, underpins guidelines established for consulting possibility of ground division. It has within its articles the dimension of corner lots chamfers, which exemplifies the delineation and functioning of projections at crossings. The proposed straight chamfers should have a minimum cathetus of 5.00 meters and/or a minimum hypotenuse of 7.07 meters (Figure 1), and in case of curve, a minimum radius of 8.00 meters (Figure 2).

Figure 1 - Straight chamfers dimensions as proposed by the city hall of Goiânia.

\section{CORNER LOT WITH STRAIGHT CHAMFER}

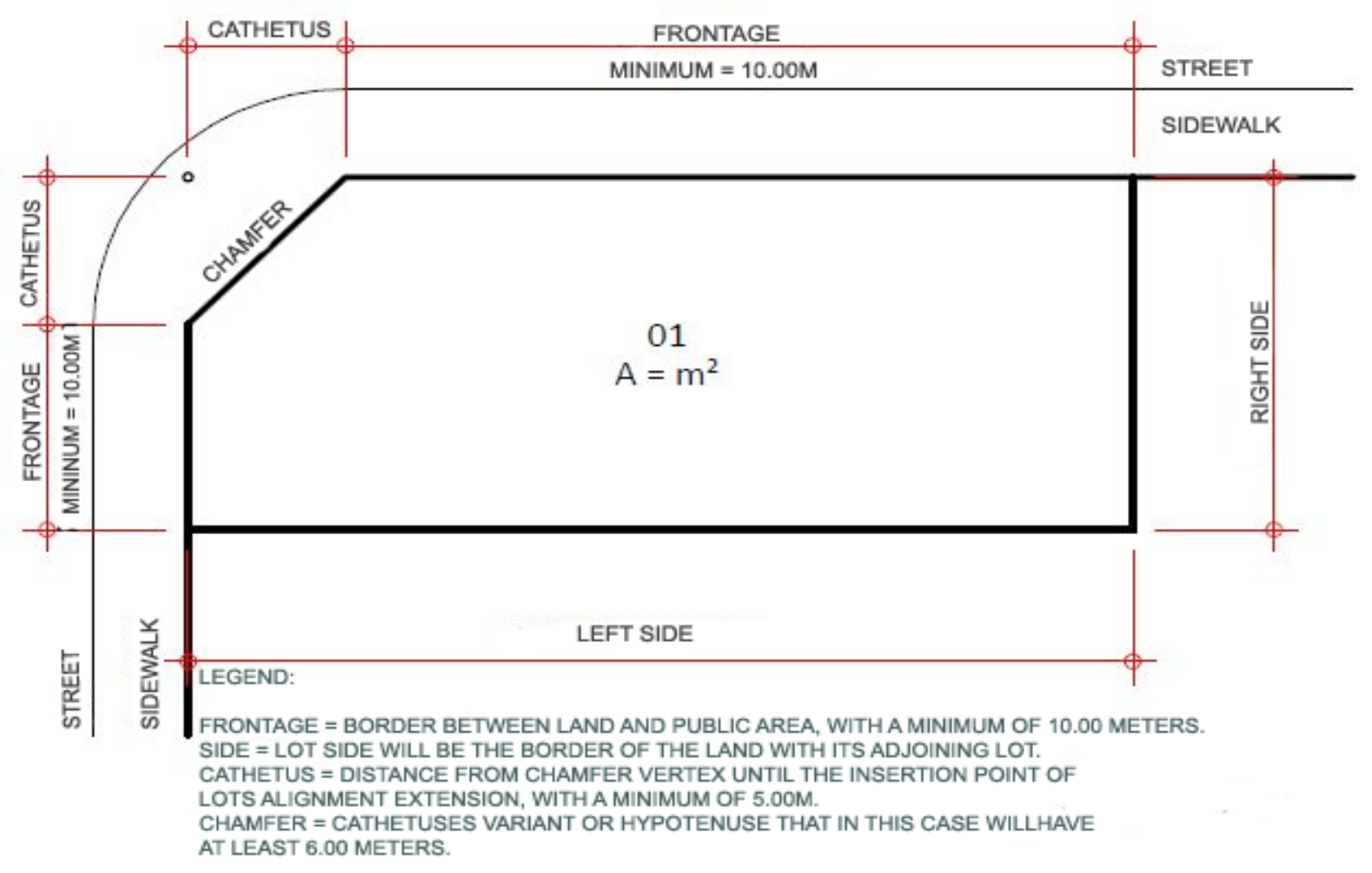

Source: Prefeitura de Goiânia (GOIÂNIA, 2017). 
Figure 2 - Circular chamfers dimensions as proposed by the city hall of Goiânia, GO

CORNER LOT WITH A CURVING CHAMFER

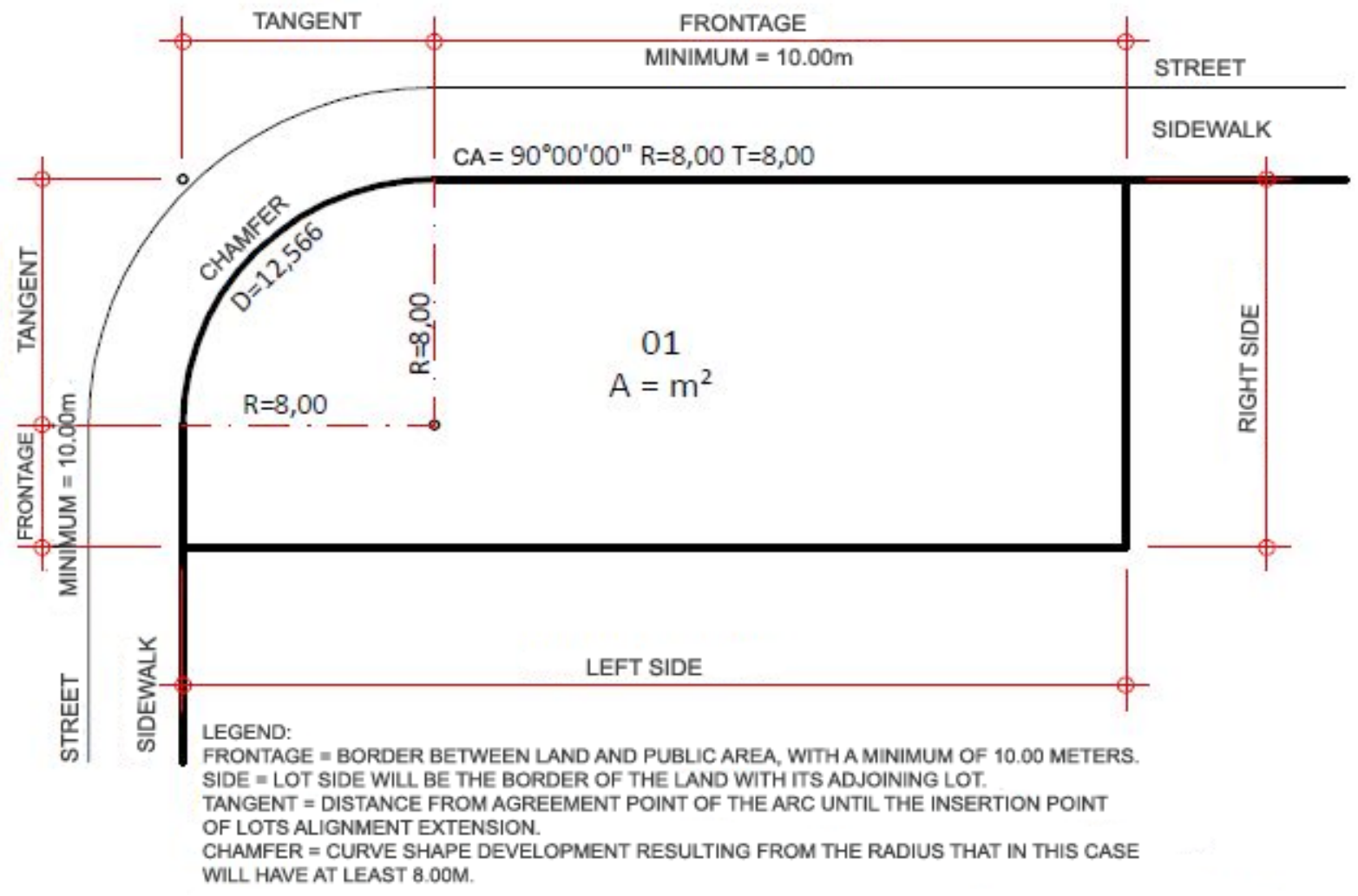

Source: Prefeitura de Goiânia (GOIÂNIA, 2017). Abbreviation "CA" stands for "Central Angle" and "T" stands for "Tangent".

In another situation, the City Hall of Jaguaribe, Ceará State, mentions in its guidelines that corner lots chamfers should have cathetuses of 3 meters and hypotenuse of $4.24 \mathrm{~m}$ (Figure 3 ).

Figure 3 - Straight chamfers dimensions as proposed by the city hall of Jaguaribe, Ceará State

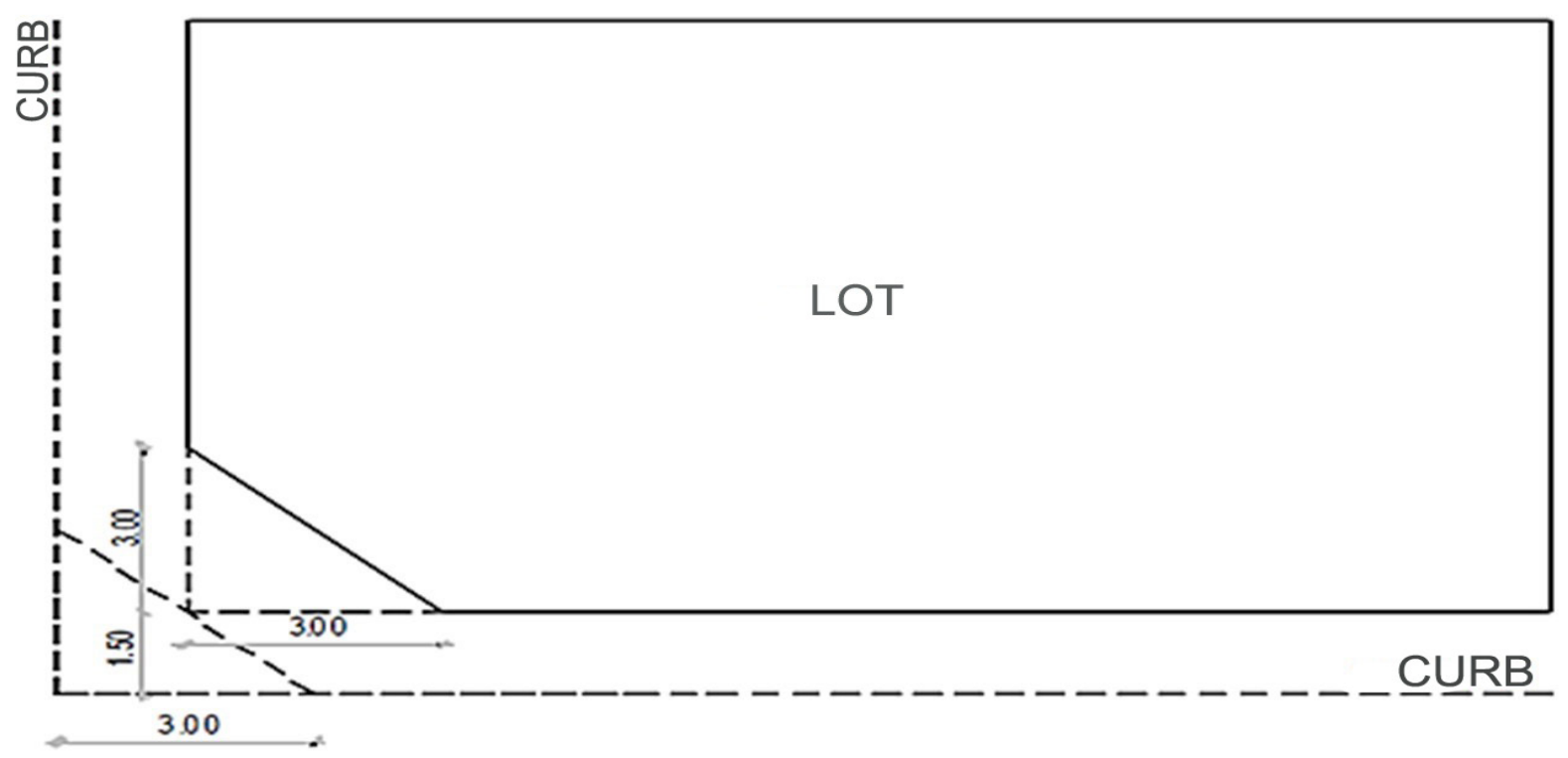

Source: Prefeitura de Jaguaribe, CE (JAGUARIBE, 2017). 
In the case of the city of Rondonópolis, in Mato Grosso State, the city hall establishes in its Building Code that corner lots chamfers shall comply with what Supplementary Law n. 91 of November 8, 2010, disposes and highlights.

It is of utmost importance that regulation of chamfers be also inserted in cities' director plans. A good example is that of the city council of Umuarama in the state of Paraná, which provides in its master plan, article 60 , that buildings, including walls, located at the intersections of public spaces should be designed, so that the two alignments have a bevel of at least 2.50 meters.

According to Mascaró (2005), radii of intersections vary depending on streets and sidewalks width and, in local streets, they should have a standard radius of 5 meters (Figure 4), which it consonant with what Moretti (1986) had already mentioned.

Figure 4 - Radius of local streets with chamfers

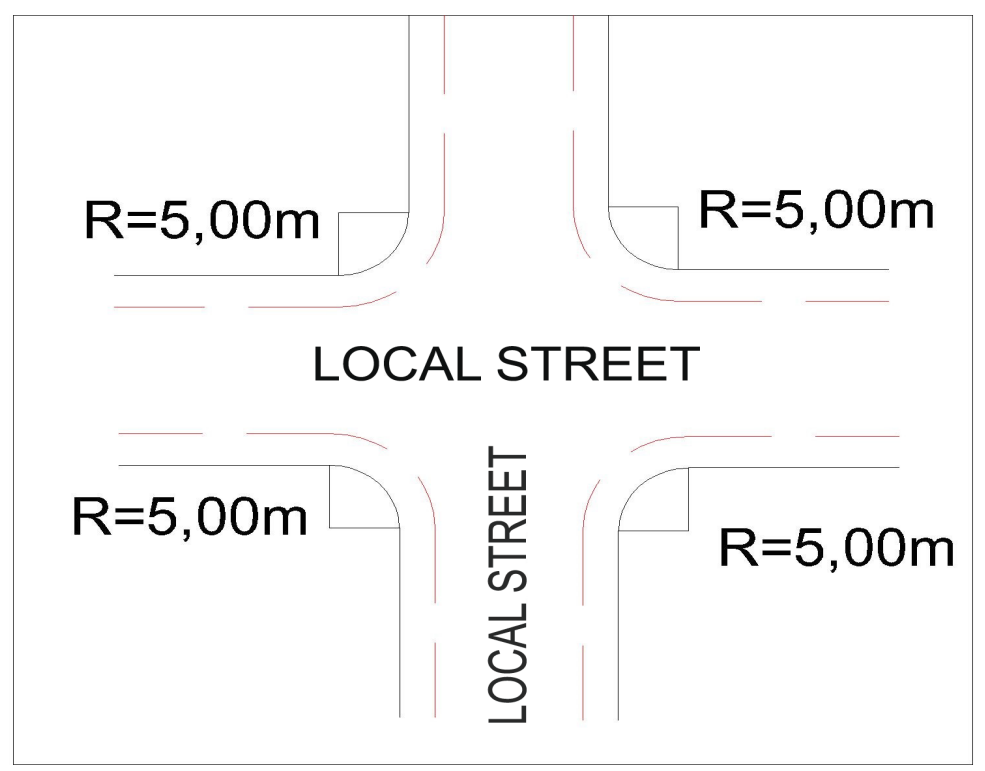

Source: Adapted from Mascaró (2003).

\section{METHODOLOGY}

Research was carried out in the Juína, MT, municipality that has an area of $26,251 \mathrm{~km}^{2}$, population of 39,779 inhabitants (IBGE, 2017) and is situated in the northwest of the state, 730 km from Cuiabá, capital of Mato Grosso State, at south latitude 11은 $42^{\prime \prime}$ and west longitude $58^{\circ} 44^{\prime} 28^{\prime \prime}$, in an altitude of 442 meters (Figure 5). The city is divided in six neighborhoods, considered as Modules, besides adjacent sectors. It encompasses two large indigenous areas and the Ecological Station of Iquê. 
Figure 5 - Location of Juína, MT

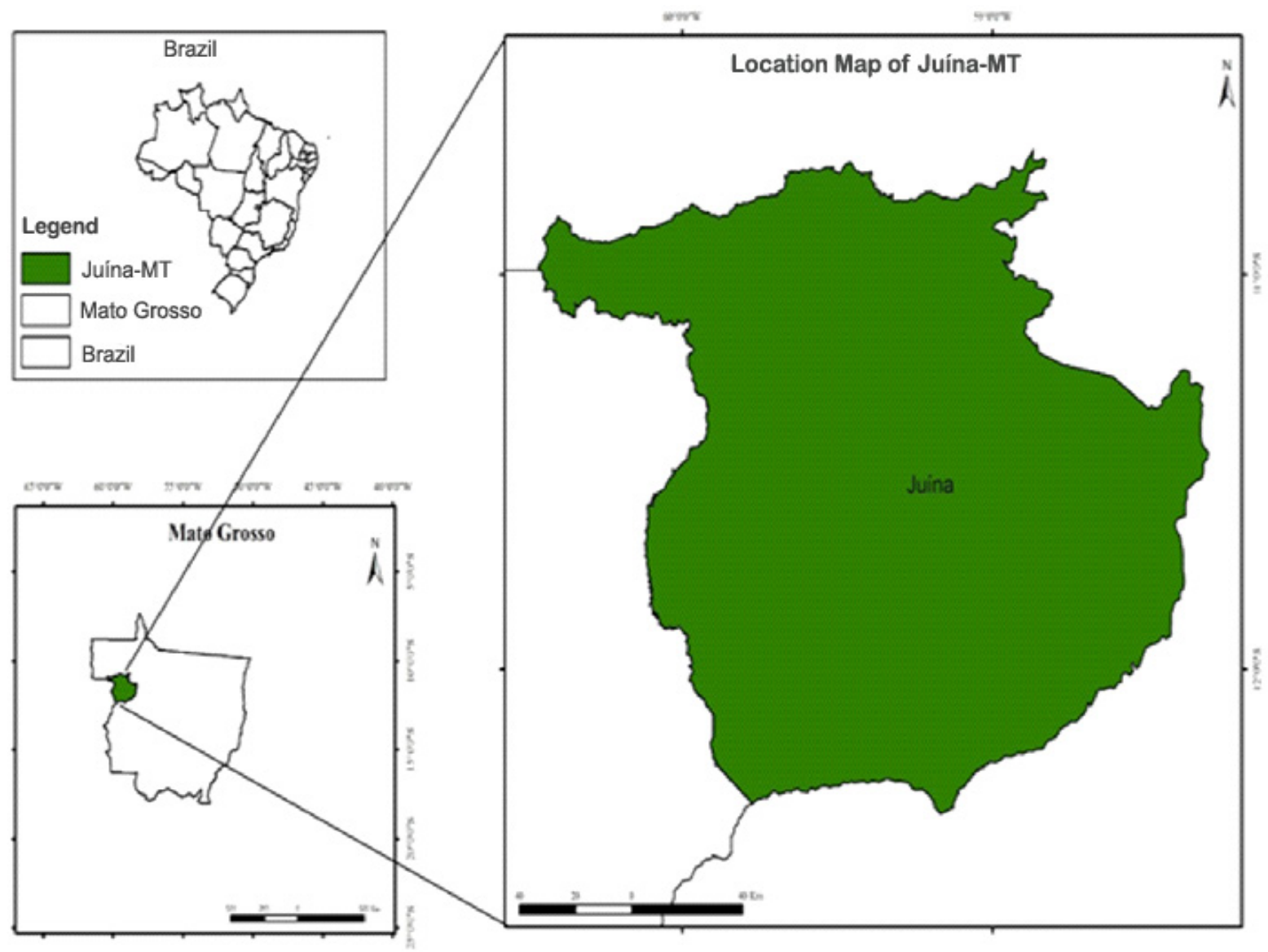

Source: Adapted from Prefeitura de Juína, MT (JUÍNA, s.d.).

In order to collect research data, in loco recognition of the area was carried out by obtaining a reading of needed information and chamfers conditions. The on-the-spot reading procedure was essential to develop effective planning and optimization of the developed work, which used topography for data collection. The applied research focused on the analysis of chamfers present in plots of the Module 1 and Module 6 neighborhoods. It collected topographic data that were subsequently processed by engineering software (SketchUp, Qgis and AutoCAD Civil 3D) and, finally, forecasts were elaborated for various situations found in points of conflict. Thus, approach was systemic and based on applied science. Vergara (1998) points out that applied research is basically generated by the need to solve visible problems, immediate or not, hence having practical purpose.

\section{RESULTS AND DISCUSSION}

When analysing crossings of the Module 1 neighborhood, those existent between the Humberto de Campos and Cristiane Casquetti streets (Figure 6) present very irregular measures. Roller track is $8.20 \mathrm{~m}$ long, sidewalk at the east of Dr. Guilherme Freitas de Abreu Lima State School is $0.39 \mathrm{~m}$ long and the sidewalk at the municipal hospital's west side is $4.70 \mathrm{~m}$ in length. 
Figure 6 -Narrow sidewalk, Module 1, Cristiane Casquetti Avenue, Juína municipality, MT

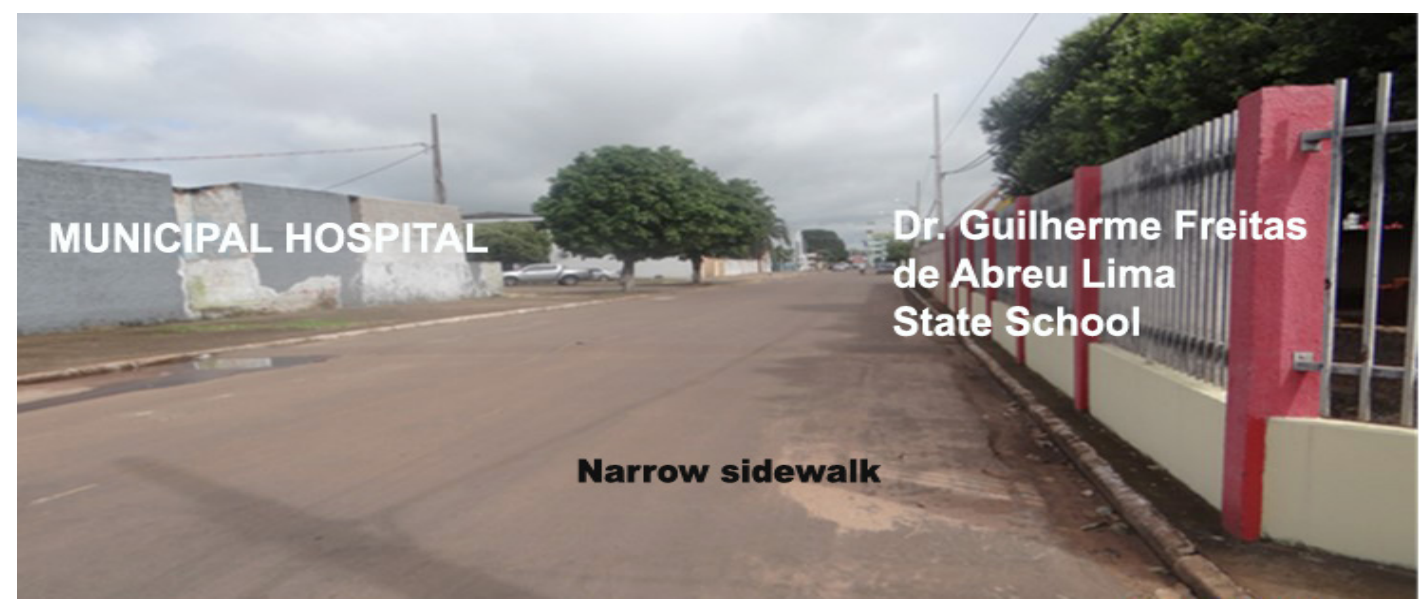

Source: Photograph and specifications by the authors, 2014.

However, it is possible to identify that several crossings of streets and avenues from the Module 1 neighborhood present serious problems related to security of pedestrians and vehicles that transit there, because there are no chamfers in bordering lots and sidewalks have inadequate measures. Therefore, visibility distances vary and compromise drivers and pedestrians' view. Moreover, crossings have around them structures that accompany building alignment in three of the four juxtapositions, which considerably worsens perceptibility as shown in Figure 7.

Figure 7 - Lack of visibility, Module 1 Neighborhood, Humberto de Campos/Cristiane Casquetti Streets, Juína municipality, MT

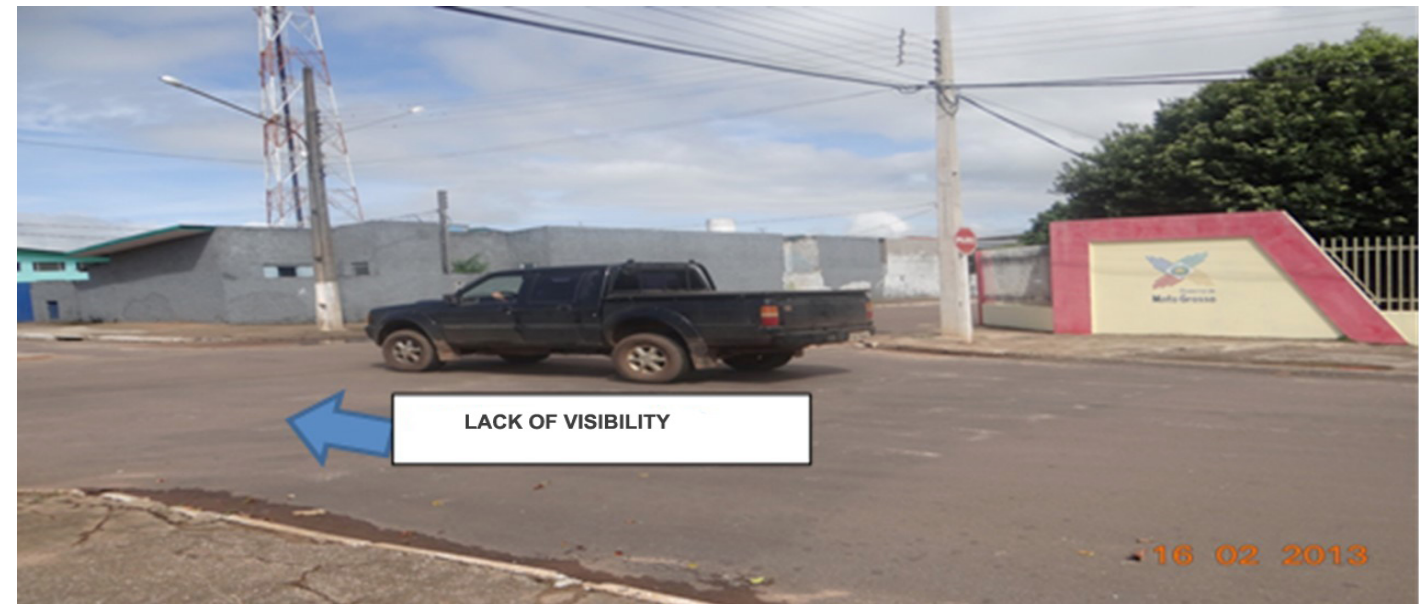

Source: Photograph and specifications by the authors, 2014.

Distance considered as the most critical for intersection is clearly noted and lack of visibility may be an obstacle for those who need to leave Humberto de Campos Street. This circumstance makes drivers need to move forward a lot in order to get a better view of the arterial highway and its flow of vehicles. Figure 8 illustrates this situation with projections and perceptions of a vehicle at the crossroad. 
Figure 8-Projections and perceptions problems of a vehicle in the crossroad, Module 1 Neighborhood, Juína municipality, MT.

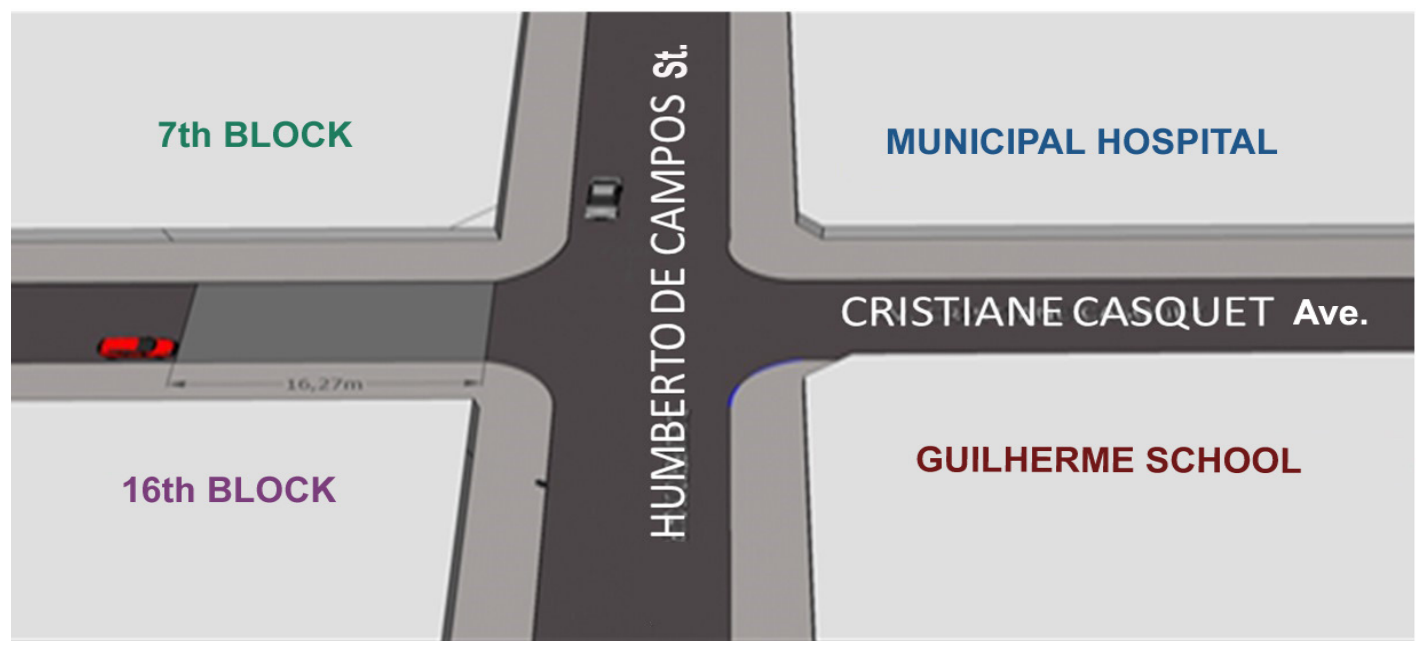

Source: Projection illustration elaborated by the authors, 2014.

The vehicle on Cristiane Casquet Avenue (Figure 8) has a field of vision starting at $16.27 \mathrm{~m}$ before crossing, being near intersection. What aggravates the situation is the position of a house wall that blocks driver's vision and impedes perception of traffic in the crossroad.

Figure 9-Visibility projection at an intersection in Module 1 Neighborhood, Juína municipality, MT

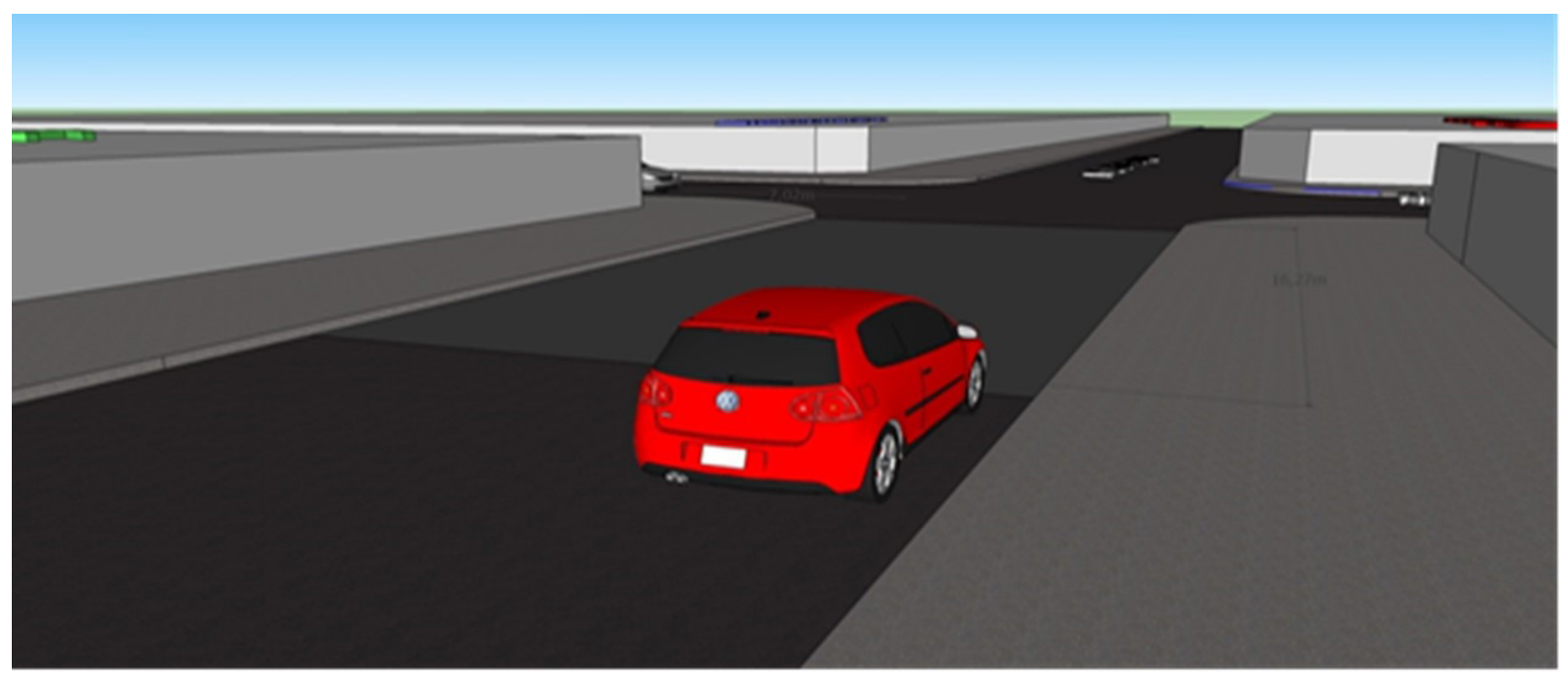

Source: Projection illustration elaborated by the authors, 2014.

Illustrations demonstrate that the field of vision is hindered by the fact that the corner lot of 16th block has no bevel. The same happens with the vehicle shown in Figure 10. 
Figure 10 - Visibility projection at an intersection in Module 1 Neighborhood, Juína municipality, MT

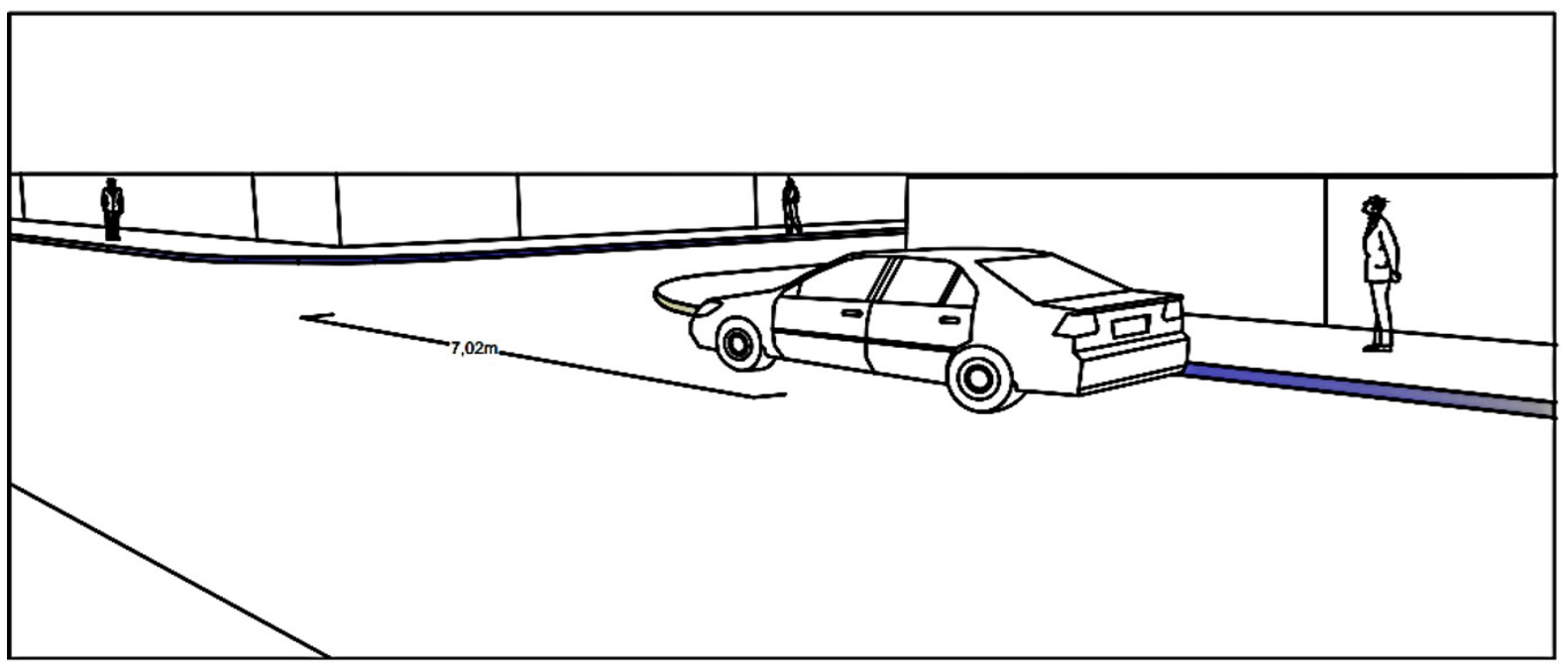

Source: Projection illustration elaborated by the authors, 2014.

It is verified that the field of vision shown in Figure 10 is even smaller than that of Figure 9, with approximately 7.02 meters with regard to the intersection projection. That occurs due to lack of chamfer and very small width of the sidewalk.

In short, owners of corner lots buildings for the most part observe execution of their projects without knowing why the corner wall cut has a straight or a circular chamfer. In that respect, common sense and some procedural adjustment may solve the problems.

In practice, however, diagnoses made on Module 6 show that problems related to lots chamfers in crossroads are greater than those of Module 1, for there are various public streets that are not yet asphalted and plots with no walls and no sidewalks (Figure 11).

Figure 11 - Intersections with problems in Module 6 Neighborhood, Juína municipality, MT

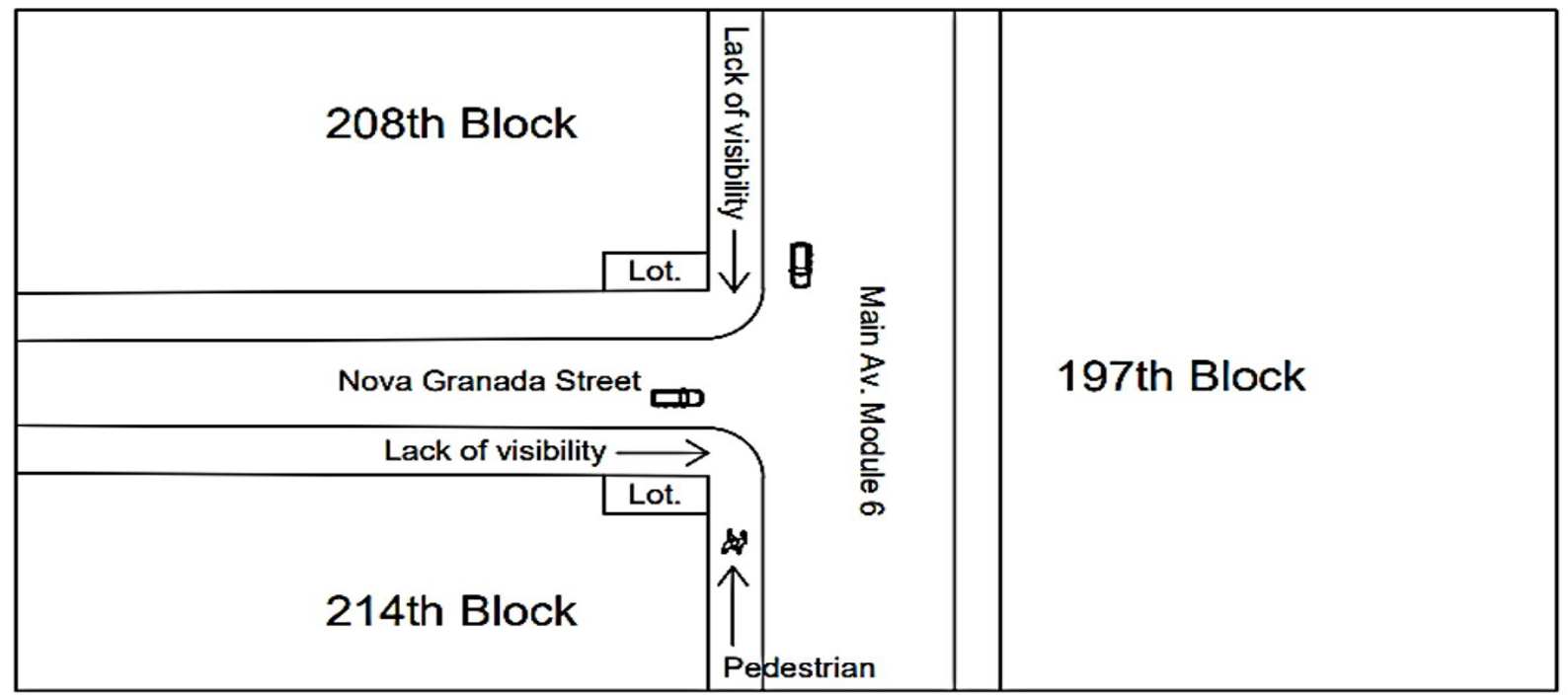

Source: Projection illustration elaborated by the authors, 2014. 
It is observed that the corner lots of the 214 and 208 blocks are not chamfered. The vehicle on Nova Granada Street has its field of vision compromised, being necessary to move the vehicle forward for a considerable distance into the main avenue, running the risk of collision. As an example, risk for pedestrians is evident at the public promenade, where they also have reduced perception about street intersection flow. It is worth emphasizing that in most cities of developed countries, streets are redesigned in order to accommodate various forms of transport and pedestrians (UN-HABITAT, 2013).

Projection drawings of figures 12, 13 and 14 show other chamfers of the Module 1 and Module 6 neighborhoods. East corner projection (Figure 12) identifies that if chamfer indentation followed an appropriate standard of 5 meters, it would result in a hypotenuse of $7.07 \mathrm{~m}$, providing visibility to the vehicle from the north side at a distance of $5.16 \mathrm{~m}$, and for that of the south, this extent would reach $2.59 \mathrm{~m}$. But the fact is that the corner possesses hypotenuse of only $1.84 \mathrm{~m}$. That difference in values may imply less braking time, causing accidents.

Figure 12 - East Corner, Module 1 Neighborhood, Juína municipality, MT

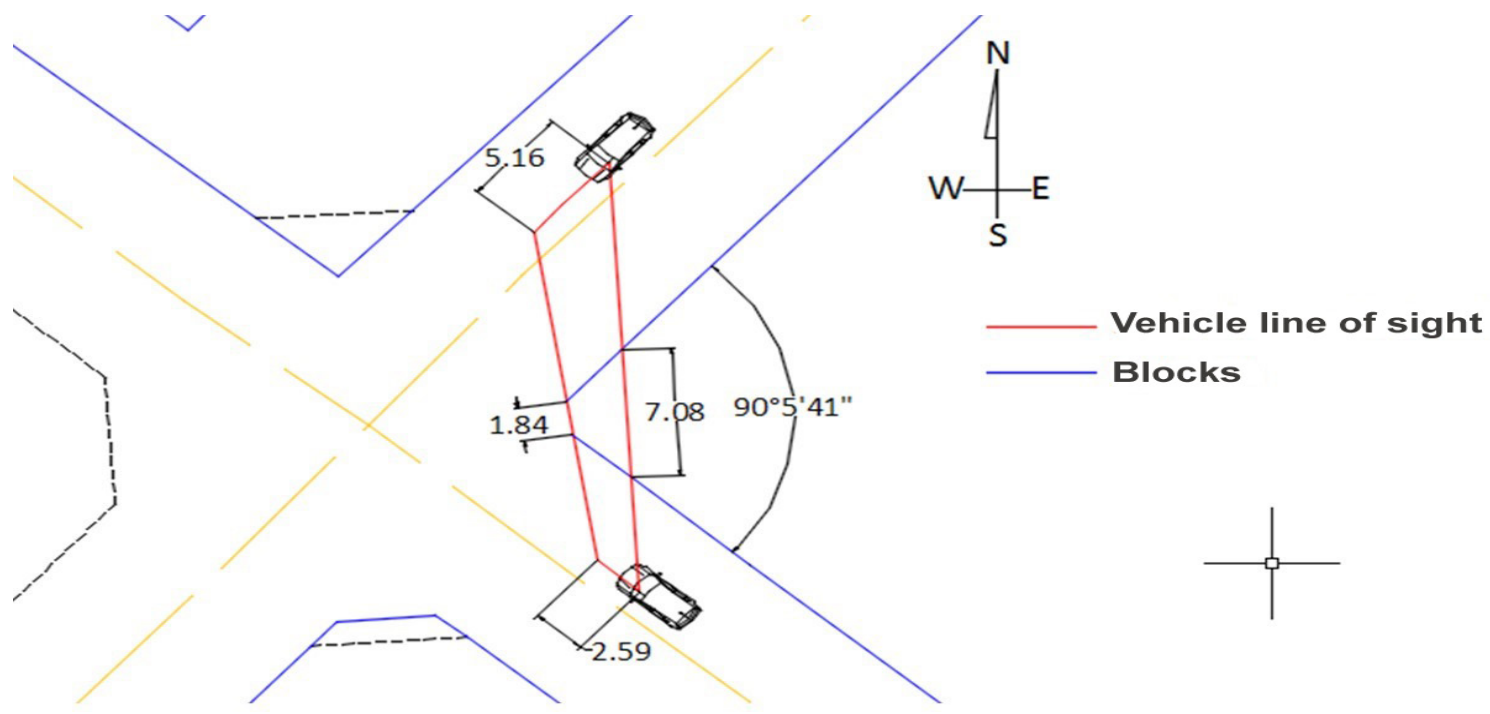

Source: Projection illustration elaborated by the authors, 2017.

West corner (Figure 13) has the ideal condition, a perpendicular corner with indentation of 5 meters that results in a hypotenuse of 7.07 meters and offers maximum visibility. 
Figure 13 - West Corner, Module 1 Neighborhood, Juína municipality, MT

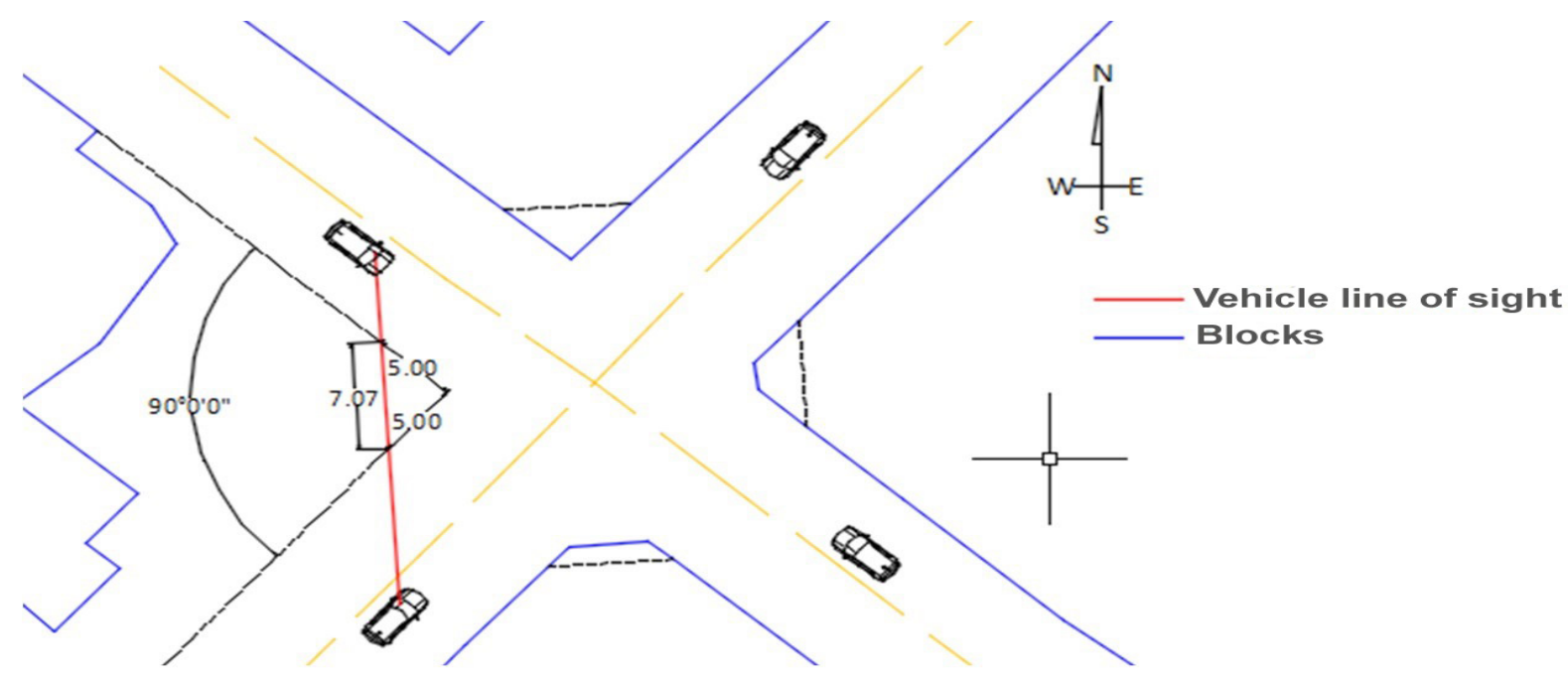

Source: Projection illustration elaborated by the authors, 2017.

The most serious scenario is observed in the north corner (Figure 14), for it has no chamfer, which according to data collected, obstructs visibility from the vehicle by $4.99 \mathrm{~m}$ on the west side and by $4.88 \mathrm{~m}$ on the east side.

Figure 14 - North Corner, Module 6 Neighborhood, Juína municipality, MT

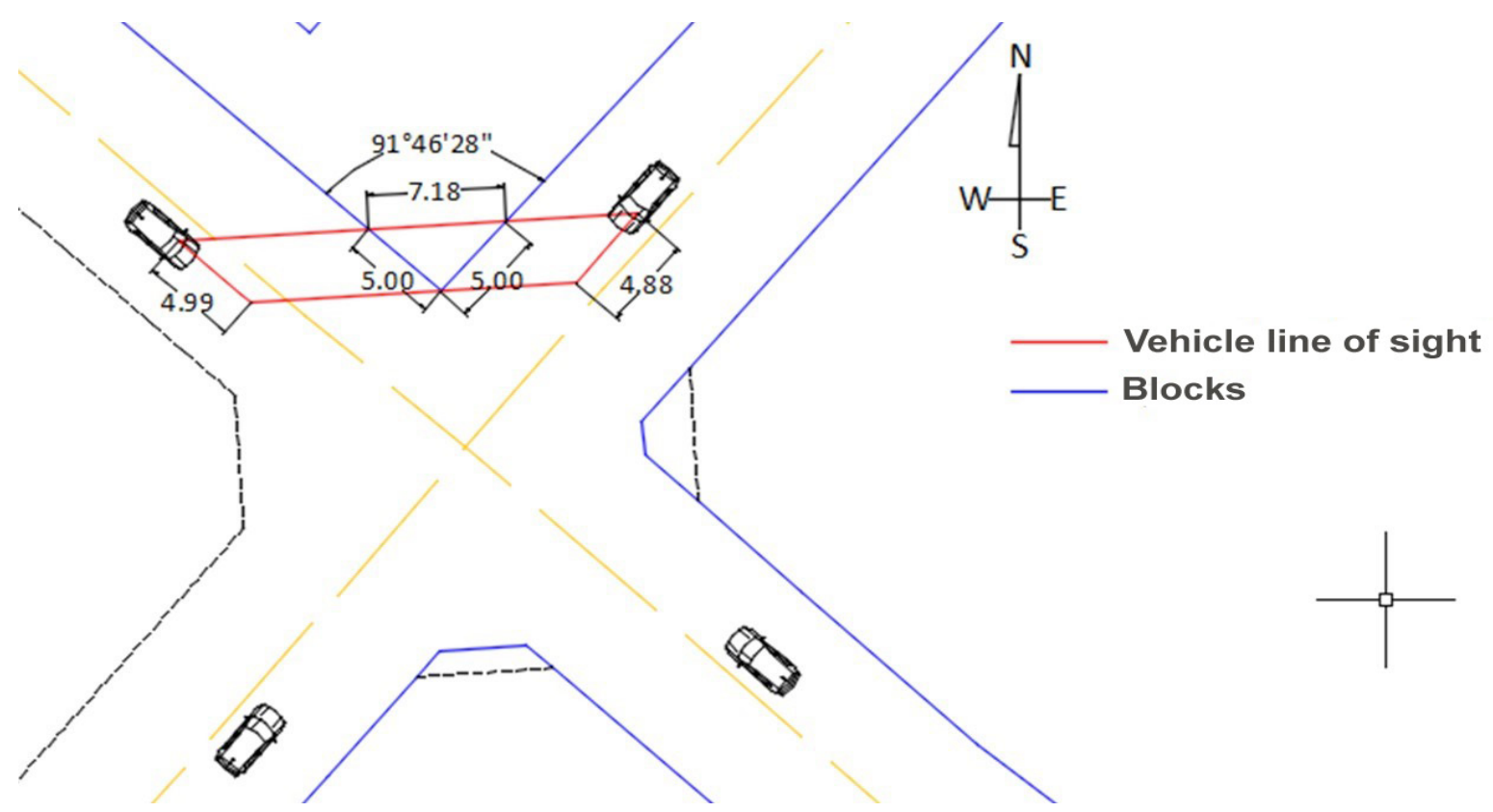

Source: Projection illustration elaborated by the authors, 2017.

Observations and analyses on mobility, accessibility and visibility of pedestrians and vehicles show that the streets of Juína need to adjust to current regulations. It is noteworthy that corners, crossroads and intersections imply the place where roads cross one another and where crossings occur with great concentration of pedestrians and vehicles (SÃO PAULO, 2009). It is at corners that a large part of interventions on sidewalks takes place, such as road signs, newsstands and 
structures related to urban infrastructure networks. These interferences damage pedestrians and drivers' visibility, with risks associated to everyone's safety. Furthermore, they restrict advances of promenade improvements, such as curb cut, chamfer adjustment in corner lots, among others.

\section{CONCLUSIONS}

The study made it possible to provide important information to comprehend chamfers situation in the so-called Module 1 and Module 6 neighborhoods of the Juína, MT municipality, whose irregularities compromise vehicles and pedestrians safety, especially in Module 6. However, this reality does not occur solely in Juína, but also in many cities of Brazil.

Projects execution in accordance with federal, state and especially municipal regulations and guidelines, when associated with efficient monitoring and adequate urban planning, will clearly contribute for reducing mobility problems and risks for pedestrians and vehicles drivers occasioned by the lack of chamfers in corner lots at roads and avenues intersections.

Despite the recognized importance of chamfers and several supplementary laws on the part of Brazilian municipalities, implementation still lacks public power effective participation, especially in monitoring and control actions, which would otherwise imply in desirable urban planning and development.

\section{REFERENCES}

BRASIL. Presidência da República. Casa Civil Subchefia para Assuntos Jurídicos. Lei Federal n. 6.766, de 19 de dezembro de 1979. Parcelamento do Solo Urbano e dá outras Providências. Disponível em: http:// www.planalto.gov.br/ccivil_03/leis/l6766.htm.Acesso em: 20 Nov. 2013.

CORRÊA, CYNTHIA CÂNDIDA; LISTON, ROSE FRANCO; BARBOSA, AGONCÍLIO CORREIA; SILVA, CLEIUDA PAES; BARCZSZ, SILVIO SILVESTRE. Gestão pública e desenvolvimento sustentável: a importância da implantação de plano diretor no ato de criação de um município. In: CONGRESSO SOBER, 48., 25-28 jul. 2010, Campo Grande, MS, 2010. Anais [...] Campo Grande, SOBER, 2010. Disponível em: http://www. sober.org.br/palestra/15/954.pdf. Acesso em: 27 Mar. 2018.

IBGE. Censo Demográfico. Município de Juína, MT. 2017. Disponível em: https://cidades.ibge.gov.br/brasil/ mt/juina. Acesso em: 25 Mar. 2018.

MASCARÓ, Juan Luis. Loteamentos Urbanos. 2. ed. Porto Alegre: Mis Quatro Editora, 2005. 210p.

MASCARÓ, Juan Luis. Loteamentos urbanos. Porto Alegre: L. Mascaró, 2003.

MORETTI, Ricardo de Souza. Loteamentos: manual de recomendações para elaboração de projeto. São Paulo: IPT, 1986. 180p.

GOIÂNIA (Cidade). Prefeitura Municipal de Goiânia. Secretaria de Habitação e Planejamento do Município. Plano diretor. Goiânia, 2017.

JUÍNA (Cidade). Prefeitura Municipal de Juína, MT. Contexto histórico da cidade de Juína. [S.d.]. Disponível em: prefeituradejuina.com.br. Acesso em: 12 Feb. 2013.

JAGUARIBE (Cidade). Prefeitura Municipal de Jaguaribe. Planos Técnicos do Brasil Ltda. 2017. Disponível em: http://conteudo.ceara.gov.br/content/aplicacao/SDLR-PDDU/_includes/PDFs/jaguaribe_ 5-LeideParcelamentodoSolo.pdf. Acesso em: 5 Feb. 2017. 
SÃO PAULO (Estado). Decreto n. 46.932, de 23 de janeiro de 2006. Recuos das edificações. In: SEMINÁRIO PAULISTANO DE CALÇADAS, 2., Nov. 2009. São Paulo: Rede Nossa São Paulo, 2009.

UNITED NATIONS HUMAM SETTLEMENTS PROGRAMME (UN-HABITAT). Streets as public spaces and drivers of urban prosperity. Nairobi: GPO KENYA, 2013. Disponível em: https://unhabitat.org/. Acesso em: 14 Mar. 2017.

VERGARA, Sylvia Constant. Projetos e relatórios de pesquisa em Administração. 2. ed. São Paulo: Atlas, 1998.

\section{About the authors:}

Rildo Vieira de Araújo: PhD student in Environmental Sciences and Agricultural Sustainability at the Dom Bosco Catholic University. MSc in Environment and Development by UNIVATES. Graduation in Technology in Surveying by the Federal Institute of Education, Science and Technology of Goiás (IFG), and Mathematics by the Universe. Professor, Geomatics, Federal Institute of Education, Science and Technology of Mato Grosso (IFMT), Barra do Garças Campus, MT. E-mail: ifmt.rildo@gmail.com

Halan Faria Lima: Master in Geography from the Federal University of Goiás (UFG) and graduation in Technology and Surveying by the Federal Institute of Science and Technology Education of Goiás (IFG) and Technical Course in Roads. Effective Professor, Geomatics área, Federal Institute of Education, Science and Technology of Goias (IFG), Goiânia Campus. E-mail: halanfl@hotmail.com

Leonice Barros Galvão: Graduated in Architecture. Architect of the City Hall of Goiânia, GO, in the area of Urban planning and architectural projects. E-mail: leobarrosgalvao@yahoo.com.br

Reginaldo Brito da Costa: PhD in Forest Sciences from the Federal University of Paraná. Master's Degree in Forestry Sciences by Luiz de Queiroz College of Agriculture. Graduation in Forestry Engineering from the Federal University of Mato Grosso. Professor of Dom Bosco Catholic University. E-mail: reg.brito.costa@gmail.com 
